\title{
Research, politics and conservation in South Africa's national parks
}

\section{BOOK TITLE:}

National park science: A century of research in South Africa

\section{BOOK COVER:}

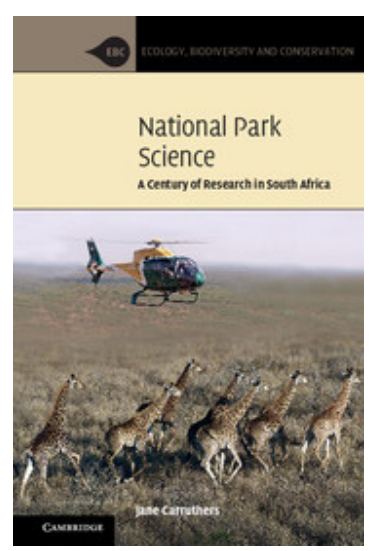

AUTHOR:

Jane Carruthers

ISBN:

9781107191440 (hardcover)

\section{PUBLISHER:}

Cambridge University Press, Cambridge; GBP67.99

\section{PUBLISHED:}

2017

\section{REVIEWER:}

Brian W. van Wilgen

\section{AFFILIATION:}

Centre for Invasion Biology, Department of Botany and Zoology, Stellenbosch University, Stellenbosch, South Africa

\section{EMAIL:}

bvanwilgen@sun.ac.za

\section{HOW TO CITE:}

Van Wilgen BW. Research, politics and conservation in South Africa's national parks. S Afr J Sci. 2018;114(1/2), Art. \#a0254, 1 page. http://dx.doi. org/10.17159/sajs.2018/a0254

(c) 2018. The Author(s). Published under a Creative Commons Attribution Licence.
National parks in South Africa have provided opportunities for scientific research in relatively pristine protected areas for over 100 years. The diversity of the parks themselves influenced the direction of the research, but the research agenda was also strongly influenced by the socio-economic and political context in which it took place. In this book, Jane Carruthers traces the development of scientific endeavours within South Africa's 19 national parks, and introduces the personalities involved. What differentiates this book from several others written by scientific practitioners - for example, Salomon Joubert's three-volume history of the Kruger National Park (KNP) ${ }^{1}$ - is that the development of research agendas and practices are examined critically in the context of the historical and political milieu within which they took place.

The earliest scientific paper to emanate from what was to become South Africa's first national park was by James Stevenson-Hamilton in 1905. At that time, there was no science of biology or ecology, and no professional training in ecosystem management. Managers were drawn from the military, but Stevenson-Hamilton, in marked contrast to his contemporaries, took a keen interest in the animals, people and environment of the vast area for which he was responsible. His books, which include accounts of the wildlife ${ }^{2}$, people ${ }^{3}$, and conservation history ${ }^{4}$ of the KNP, laid a foundation for future work in protected areas. In fact, for the first half of the 20th century, the history of research in national parks revolved almost exclusively around Stevenson-Hamilton.

Following World War II, pressure from scientists saw the creation of a Scientific Advisory Council, but it was not very influential. What was more influential was the report of a commission chaired by Prof. P.W. Hoek, which identified widespread and concerning practices. These included the appointment of unqualified people who neglected their duties, displayed no interest in conservation, and used the protected areas to run their livestock. This led to a restructuring of the organisation, and was followed by the appointment in 1950 of three scientists at the KNP, including T.G. Nel, the first trained biologist to be employed. Nel in turn appointed Dr U. de V. (Tol) Pienaar, another trained biologist, in 1955. Pienaar became very influential, rising to warden of the KNP in 1978, and to Chief Director of the National Parks Board from 1987 to 1991. The period from 1960 until the early 1990s was characterised by the National Parks Board's own brand of research that sought to 'measure, monitor and manipulate'. The period saw the development of an inward-looking research philosophy in which the national parks scientists regarded their understanding as adequate, and they saw no need for outside opinions.

The 1970s and early 1980s saw profound changes to the practise of ecological science in South Africa. Brian Huntley established co-operative research programmes at the Council for Scientific and Industrial Research, headed by academics as well as government scientists. Several 'biome projects' (savanna, fynbos, karoo, forest and grassland) led to deeper understanding of ecology and predictive models, and the training of a new breed of young ecologists. However, the national parks scientists did not participate in these programmes, and remained 'supremely self-confident and regarded outside interest as unwarranted interference'. This is not to say that national parks were not productive; a large number of checklists and descriptive studies were conducted, making a contribution to understanding by providing important foundational building blocks for ecological science.

Further and inevitable changes to research agendas came about in the 1990s. Robbie Robinson, the new CEO of national parks, adopted English as the language of formal communication, suspended elephant culling (much to the dismay of the KNP's scientists), established new national parks with new collaborative management models, and gave greater powers to the regions. He also oversaw the creation of a new 'Scientific Services' division, with regional offices, and created a social ecology unit. In 1994, he invited Richard Bell (a highly regarded wildlife researcher) to review the past work of researchers - a bold move by Robinson, as the organisation had never been peer reviewed. Bell's report found that the KNP master plan was 'deeply flawed - woolly in language, conceptually vague, and containing nothing about how scientific research should be conducted'. It was another wake-up call.

In South Africa, a democratically elected government was installed in 1994, which opened the doors to international research funding, and led to more changes to South African National Park's Scientific Services. Research shifted from a paradigm of 'command and control' to one of strategic adaptive management; curiosity-driven research was introduced alongside the descriptive research; the research team was significantly diversified; and new research centres were established. Led by the dynamic and energetic Harry Biggs (with able support from Kevin Rogers and Charles Breen, both external academics), the new paradigm of strategic adaptive management was developed and tested.

Reading through this book, I was struck by two things. Firstly, this is mainly about the KNP, with research in other national parks playing a minor role, at least until recently. Nonetheless, research in 'other national parks' is more than adequately covered. Secondly, a small number of strong leaders played a fundamental role in shaping the research agenda over the past century: James Stevenson-Hamilton, Tol Pienaar, Robbie Robinson and Harry Biggs. This book is a fascinating account of the journey that they took, the socio-political context within which they operated, and the legacy that they left - both in the published literature and in the establishment and development of a suite of national parks. I would recommend this book highly to researchers and students active in protected areas in South Africa and beyond, as well as to anyone with an interest in the history and management of our national parks.

\section{References}

1. Joubert SCJ. The Kruger National Park: A history. Johannesburg: High Branching; 2012.

2. Stevenson-Hamilton J. Animal life in Africa. London: Heinemann; 1912.

3. Stevenson-Hamilton J. The Lowveld: Its wildlife and its people. London: Cassell; 1929.

4. Stevenson-Hamilton J. South African Eden. London: Cassell \& Co.; 1937. 